\title{
Effects of L-Histidine and Sodium Acetate on $\beta$-Casein Expression in Nutrient-Restricted Bovine Mammary Epithelial Cells
}

\author{
Jungeun Kim ${ }^{1,2}$ and Hong-Gu Lee ${ }^{1,2, *(1)}$ \\ 1 Department of Animal Science and Technology, Sanghuh College of Life Sciences, Konkuk University, \\ Seoul 05029, Korea; sumzzzing@gmail.com \\ 2 Team of Educational Program for Specialists in Global Animal Science, Brain Korea 21 Plus Project, \\ Konkuk University, Seoul 05029, Korea \\ * Correspondence: hglee66@konkuk.ac.kr; Tel.: +82-2-450-0523
}

Citation: Kim, J.; Lee, H.-G. Effects of L-Histidine and Sodium Acetate on $\beta$-Casein Expression in

Nutrient-Restricted Bovine Mammary Epithelial Cells. Animals 2021, 11, 1444. https://doi.org/10.3390/ ani11051444

Academic Editor: Lorenzo E. Hernández Castellano

Received: 22 March 2021

Accepted: 15 May 2021

Published: 18 May 2021

Publisher's Note: MDPI stays neutral with regard to jurisdictional claims in published maps and institutional affiliations.

Copyright: (c) 2021 by the authors. Licensee MDPI, Basel, Switzerland. This article is an open access article distributed under the terms and conditions of the Creative Commons Attribution (CC BY) license (https:/ / creativecommons.org/licenses/by/ $4.0 /)$.
Simple Summary: Nutrient restriction is known to decrease the milk production and milk quality of dairy cows. However, providing cows with abundant nutrients also has a disadvantage because it will increase feed costs. Under such a situation, the use of feed additives can be a good strategy to reduce the feed cost. The objective of this study was to investigate the effects of histidine and sodium acetate on $\beta$-casein expression in nutrient-restricted bovine mammary epithelial cells. The results indicate that histidine has the potential to increase the $\beta$-casein levels in bovine mammary cells when the nutrient is restricted, suggesting that histidine is a potential feed additive for cows in a nutrient-insufficient environment.

Abstract: Nutrient restriction is a challenging condition for the mammary glands of dairy cows. In this condition, supplementing amino acids and energy sources might be a good strategy to improve the concentration of one of the most important caseins in bovine milk. Therefore, the objective of this study was to investigate the effects of L-histidine (His) and sodium acetate (Ace) in a nutrient-restricted (NR) immortalized bovine mammary epithelial cell line (MAC-T cells). The treatments for the MAC-T cells are as follows: experiment (1) 0-5\% diluted basal medium; experiment (2) supplementation of $0-9.6 \mathrm{mM}$ of His or Ace in NR or normal conditions; experiment (3) supplementation of $0-9.6 \mathrm{mM}$ of Ace plus $0.15 \mathrm{mM}$ of His in NR or normal conditions. The $1 \%$ diluted medium showed no significant effect on the cell viability with the basal medium; thus, it was selected as the NR condition. The relative expression of $\beta$-casein was significantly increased in the NR condition with the inclusion of $0.15 \mathrm{mM}$ His alone or with Ace compared to that in control. The supplementation of Ace increased the $\beta$-casein level under normal conditions. However, it did not change the expression of $\beta$-casein under the NR condition. The results suggest that His has the potential to increase the $\beta$-casein expression under the NR condition.

Keywords: L-histidine; sodium acetate; nutrient restriction; $\beta$-casein; bovine mammary epithelial cells

\section{Introduction}

Lactating cows require significant amounts of nutrients and energy to produce milk for their offspring; thus, nutrient restriction (NR) is a challenging condition for dairy cows. Bovine mammary glands can produce milk proteins. Amino acids (AAs), energy sources, and hormones are essential components for milk protein synthesis [1]. AAs, as components of proteins, have biological roles in animal bodies. Many studies have reported that treatment with AAs can stimulate protein synthesis in mammary epithelial cells in vitro [2-4]. Protein synthesis mediated by nutrients is related to the mammalian target of rapamycin (mTOR) pathway $[1,5,6]$. The mTOR is a central protein complex of 
the protein synthesis cascade, and is activated by several factors. Once activated, mTOR can phosphorylate ribosomal protein S6 kinase 1 (S6K1) and ribosomal protein S6 (RPS6). Casein gene expression and protein synthesis are then achieved through the translation initiation and elongation process [7].

The supplementation of AA maintained or increased milk production when the cows were fed reduced dietary crude protein [8]. However, knowledge about the effect of single AA on nutrient-restricted (NR) mammary cell levels is limited. Histidine (His), one of essential AAs for dairy cows, maintained the milk protein levels when the cows were fed a metabolizable protein-deficient diet $[9,10]$. Furthermore, His has been reported to have a stimulatory effect on the mTOR pathway-related genes in mammary epithelial cells $[4,11]$. Protein synthesis is a highly energy-demanding process. Acetate (Ace) is a precursor of milk fat and an energy source for ruminants, and its ability to stimulate milk protein synthesis have been reported in mammary epithelial levels [12,13]. Thus, His and Ace might be useful for verifying their effects on $\beta$-casein mRNA expression in mammary epithelial cells under NR conditions.

Therefore, the objective of the present study was to evaluate the effects of His and Ace on $\beta$-casein expression in immortalized bovine mammary epithelial cells under a NR condition in vitro. The hypothesis was that the NR condition would modulate the effects of His and Ace differently from the normal conditions.

\section{Materials and Methods}

\subsection{Reagents}

Dulbecco's modified Eagle's medium (DMEM/F12), fetal bovine serum (FBS), penicillin/streptomycin, Pierce ${ }^{\mathrm{TM}}$ BCA protein assay kit, and bovine serum albumin (BSA) were obtained from Thermo Scientific (South Logan, UT, USA). Gentamycin, insulin, hydrocortisone, prolactin, L-histidine, and sodium acetate were purchased from Sigma-Aldrich (St. Louis, MO, USA). The cell counting kit-8 (CCK-8) solution was obtained from Dojindo Laboratories (Rockville, MD, USA). Phosphate-buffered saline (PBS) was purchased from Biosesang (Seongnam, Korea). The TRI Reagent was obtained from MRC (Cincinnati, OH, USA). An iScript cDNA synthesis kit was purchased from Bio-Rad (Foster Cty, CA, USA). The AccuPower ${ }^{\circledR} 2 X$ GreenStar ${ }^{\mathrm{TM}}$ qPCR MasterMix was obtained from Bioneer (Seoul, Korea).

\subsection{Cell Culture and Experimental Design}

Immortalized bovine mammary epithelial cells (MAC-T cells) were obtained from Dr. Feng-Qi Zhao (University of Vermont, Burlington, VT, USA). The MAC-T cells were incubated as reported previously, with minor modifications [14-16]. Briefly, the cells were cultured in $10-\mathrm{cm}$ plates with basal growth medium at $37^{\circ} \mathrm{C}$ with $5 \% \mathrm{CO}_{2}$. The basal growth medium was DMEM/F12 containing 10\% FBS, 100 units/mL penicillin/streptomycin, $50 \mu \mathrm{g} / \mathrm{mL}$ gentamycin, $5 \mu \mathrm{g} / \mathrm{mL}$ insulin, and $1 \mu \mathrm{g} / \mathrm{mL}$ hydrocortisone. After this, the cells were transferred to 6-well plates $\left(5 \times 10^{4}\right.$ cells/well) for the treatments. When the cells reached $80 \%$ confluence, they were serum-starved overnight and then cultured with a differentiation medium (DIF) (DMEM/F12 containing 100 units/mL penicillin/streptomycin, $50 \mu \mathrm{g} / \mathrm{mL}$ gentamycin, $5 \mu \mathrm{g} / \mathrm{mL}$ insulin, $1 \mu \mathrm{g} / \mathrm{mL}$ hydrocortisone, and $5 \mu \mathrm{g} / \mathrm{mL}$ prolactin) with various treatments for $24 \mathrm{~h}$. The morphology of the MAC-T cells is presented in Figure 1. The treatment media were as follows: experiment (1) basal DIF diluted with distilled water $(100 \%, 99 \%, 98 \%, 97 \%, 96 \%$, and $95 \% \mathrm{DIF}$, respectively); experiment (2) $100 \%$ DIF or $99 \%$ DIF with $0,0.15,0.3,0.6,1.2,2.4,4.8$, and $9.6 \mathrm{mM}$ of His or Ace; experiment (3) $100 \%$ DIF or $99 \%$ DIF plus $0.15 \mathrm{mM}$ of His with $0,0.15,0.3,0.6,1.2,2.4,4.8$, and $9.6 \mathrm{mM}$ of Ace. The initial concentrations of the His and Ace in the complete DMEM/F12 were $0.15 \mathrm{mM}$ and $0 \mathrm{mM}$, respectively. The MAC-T cells were involved in a completely randomized design. In each treatment, an independent well was considered as the experimental unit. All of the experiments were replicated three times on three different days. 


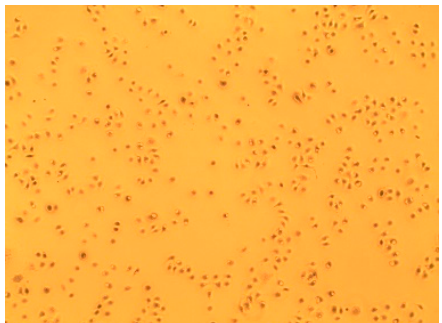

(a)

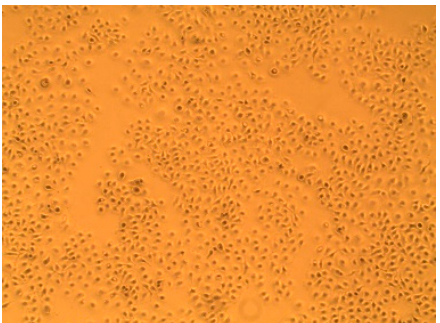

(b)

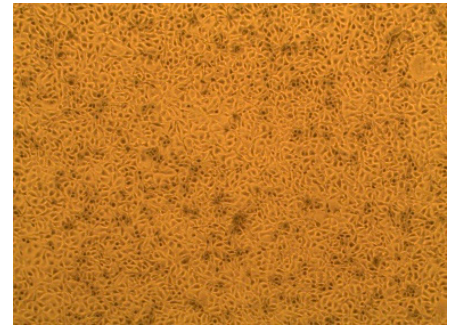

(c)

Figure 1. The morphology of the immortalized bovine mammary epithelial cells used in this study (magnification $\times 10$; Olympus Co., Shinjuku, Tokyo, Japan). (a) $24 \mathrm{~h}$ growth, (b) $48 \mathrm{~h}$ growth, and (c) at the starting time for the treatments of the MAC-T cells in the 6-well plates.

\subsection{Cell Viability}

The cell viability was determined using the CCK-8 solution according to the manufacturer's instructions. Briefly, MAC-T cells were seeded into 96-well plates with $100 \mu \mathrm{L}$ growth medium (5000 cells/well) and pre-incubated at $37^{\circ} \mathrm{C}$ with $5 \% \mathrm{CO}_{2}$ for $24 \mathrm{~h}$. The spent medium was then replaced for each treatment medium and the cells were incubated for another $24 \mathrm{~h}$. The CCK-8 solution $(10 \mu \mathrm{L} /$ well $)$ was added at $1 \mathrm{~h}$ before the end of this $24 \mathrm{~h}$ of incubation. The relative cell viability was determined by measuring at the absorbance at $450 \mathrm{~nm}$ using a microplate reader (Synergy2, BioTek, Winooski, VT, USA).

\subsection{Protein Quantification}

The cultured supernatants were collected in order to analyze the protein concentration. The samples were centrifuged at $300 \times g$ for $5 \mathrm{~min}$ at $4{ }^{\circ} \mathrm{C}$. The supernatants were then carefully transferred to new tubes in order to measure the protein concentrations using a Pierce ${ }^{\mathrm{TM}} \mathrm{BCA}$ protein assay kit according to the manufacturer's instructions by measuring the absorbance of $562 \mathrm{~nm}$ using a microplate reader (Synergy2). BSA was used to generate the standard curve.

\subsection{Gene Expression}

After incubation with each treatment medium, MAC-T cells were washed twice with 1 X PBS. After the cells were harvested, the total RNA was extracted using a TRI Reagent. The quantity and quality of the RNA were analyzed using a NanoDrop $100{ }^{\circledR}$ Spectrophotometer (Thermo Scientific, Seoul, Korea). RNA with 260/280 ratio of 1.8 to 2.0 and a $260 / 230$ ratio of more than 2.0 were considered acceptable. This RNA was then used for the cDNA synthesis with an iScript cDNA synthesis kit according to the manufacturer's instructions. The real-time polymerase chain reaction (RT-PCR) was performed using a CFX Connect ${ }^{\mathrm{TM}}$ Real-Time System (Bio-Rad, Seoul, Korea) with AccuPower ${ }^{\circledR} 2 \mathrm{X}$ GreenStar ${ }^{\mathrm{TM}} \mathrm{qPCR}$ MasterMix in order to determine the target gene expression levels. The PCR conditions were as follows: $95^{\circ} \mathrm{C}$ for $3 \mathrm{~min}$, followed by 40 cycles at $95^{\circ} \mathrm{C}$ for $10 \mathrm{~s}$, $55-65^{\circ} \mathrm{C}$ for $30 \mathrm{~s}$, and $72{ }^{\circ} \mathrm{C}$ for $30 \mathrm{~s}$. The primer sequences used in this study are listed in Table 1. $\beta$-actin and ubiquitously expressed transcript protein (UXT) were used for the normalization of the target genes $[17,18]$. The target gene expression adjusted by multiple reference genes was conducted using Bio-Rad CFX Manager 3.1 software (Bio-Rad). 
Table 1. List of primer sequences used for the real-time polymerase chain reaction (RT-PCR) analysis.

\begin{tabular}{|c|c|c|c|}
\hline Gene $^{1}$ & Accession No. & Type $^{2}$ & Sequence $\left(5^{\prime}-3^{\prime}\right)$ \\
\hline \multirow[t]{2}{*}{ ASCT2 } & NM_174601.2 & $\mathrm{F}$ & TGCCGCTGATGATGAAGTGT \\
\hline & & $\mathrm{R}$ & AGTCCACGGCCAAGATCAAG \\
\hline \multirow[t]{2}{*}{ GLUT1 } & NM_174602.2 & $\mathrm{F}$ & TCGCTTCATCATCGGTGTGT \\
\hline & & $\mathrm{R}$ & GCTTCTTCAGCACGCTCTTG \\
\hline \multirow[t]{2}{*}{ LAT1 } & AF174615 & $\mathrm{F}$ & TACTTCCTTGGGGTCTGGTG \\
\hline & & $\mathrm{R}$ & GTATCTGCGGACATCCACCT \\
\hline \multirow[t]{2}{*}{ mTOR } & XM_002694043.6 & $\mathrm{F}$ & ATGCTGTCCCTGGTCCTTAT \\
\hline & & $\mathrm{R}$ & GGGTCAGAGAGTGGCCTTCA \\
\hline \multirow[t]{2}{*}{ RPS6 } & NM_001015548.2 & $\mathrm{F}$ & TGAAGCAGGGTGTCTTGACC \\
\hline & & $\mathrm{R}$ & TCCAGTCCTCCTTGGTCTGT \\
\hline \multirow[t]{2}{*}{ S6K1 } & NM_205816.1 & $\mathrm{F}$ & GGACATGGCAGGGGTGTTT \\
\hline & & $\mathrm{R}$ & GGTATTTGCTCCTGTTACTT \\
\hline \multirow[t]{2}{*}{ UXT } & NM_001037471.2 & $\mathrm{F}$ & GCGCTACGAGGCTTTCATCT \\
\hline & & $\mathrm{R}$ & CCAAGGGCCACATAGATCCG \\
\hline \multirow[t]{2}{*}{$\beta$-actin } & NM_173979.3 & $\mathrm{F}$ & GCATGGAATCCTGCGGC \\
\hline & & $\mathrm{R}$ & GTAGAGGTCCTTGCGGATGT \\
\hline \multirow[t]{2}{*}{$\beta$-casein } & XM_015471671.2 & $\mathrm{F}$ & GAGCCTGACTCTCACTGATGTTGAA \\
\hline & & $\mathrm{R}$ & GACAGCACGGACTGAGGAGGAA \\
\hline
\end{tabular}

${ }^{1}$ ASCT2 = sodium-dependent neutral amino acid transporter type 2; GLUT1 = glucose transporter 1; LAT1 = large neutral amino acids transporter small subunit $1 ; m T O R$; mammalian target of rapamycin; RPS6 = ribosomal protein $\mathrm{S} 6 ; \mathrm{S} 6 \mathrm{~K} 1$ = ribosomal protein S6 kinase 1; UXT = ubiquitously expressed transcript protein. ${ }^{2} \mathrm{~F}=$ forward; $\mathrm{R}=$ reverse.

\subsection{Statistical Analysis}

The data were analyzed using the GLM procedure of SAS version 9.4 (SAS Institute Inc., Cary, NC, USA). The cell viability, relative protein concentrations, and relative gene expression were analyzed with Tukey's multiple comparison or $t$-test. The differences between the treatment groups were considered significant at $p<0.05$.

\section{Results}

\subsection{Effect of NR on MAC-T Cell Viability}

The effect of the diluted differentiation medium on the relative MAC-T cell viability is shown in Figure 2. The cell viability decreased with an increase of the dilution rate in the differentiation medium $(p<0.001)$. The treatment group of $99 \%$ DIF showed higher relative viability $(92 \%)$ than the groups treated with further dilutions $(\leq 61 \%)$. Thus, $99 \%$ DIF was selected as the NR condition for the MAC-T cells.

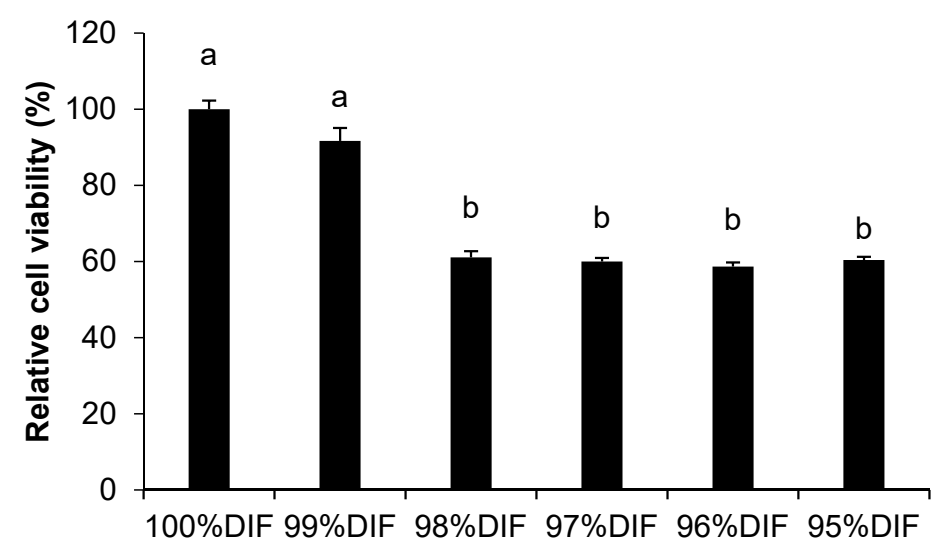

Figure 2. The effect of nutrient-restricted differentiation medium (DIF) on the viability of immortalized bovine mammary epithelial cells (MAC-T). The MAC-T cells were incubated with $0-5 \%$ nutrient-restricted DIF for $24 \mathrm{~h}$. The values are presented as the mean $\pm \operatorname{SEM}(n=3)$. The means without a superscript letter differ $(a, b), p<0.05$. 


\subsection{Individual Effects of His and Ace under the NR Condition}

The effects of His, Ace, or NR on the relative viability of the MAC-T cells are shown in Figure 3. The relative cell viability was decreased by His in a dose-dependent manner regardless of the NR condition $(p<0.0001$, Figure $3 \mathrm{a}, \mathrm{b})$. The cell viability was also decreased by Ace in a dose-dependent manner under the 100\%DIF condition ( $p=0.004$, Figure 3c). Statistical changes of the cell viability were not observed for the groups treated with $0-2.4 \mathrm{mM}$ of Ace and $99 \%$ DIF. However, the relative cell viability was decreased in groups treated with 4.8-9.6 mM of Ace and 99\%DIF ( $p<0.001$, Figure 3d). For the subsequent analyses, the treatment groups that showed no statistically significant difference in their cell viability compared to the group treated with $100 \%$ DIF without any supplementation of His or Ace were selected: $0-1.2 \mathrm{mM}$ of His with $100 \%$ DIF, $0-0.6 \mathrm{mM}$ of His with $99 \%$ DIF, $0-2.4 \mathrm{mM}$ of Ace with $100 \% \mathrm{DIF}$, and $0-2.4 \mathrm{mM}$ of Ace with $99 \% \mathrm{DIF}$.

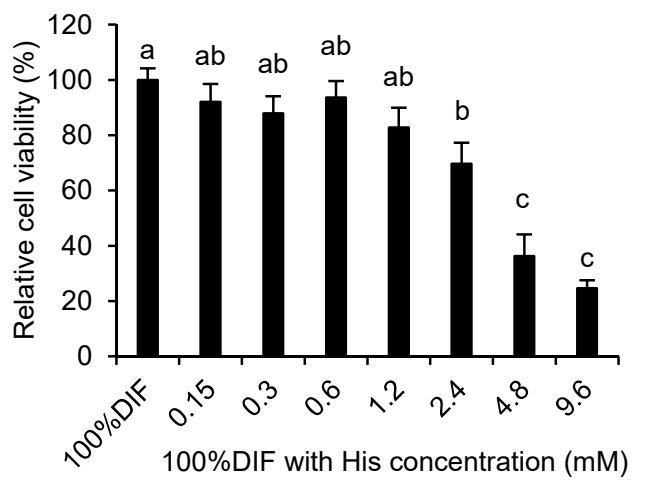

(a)

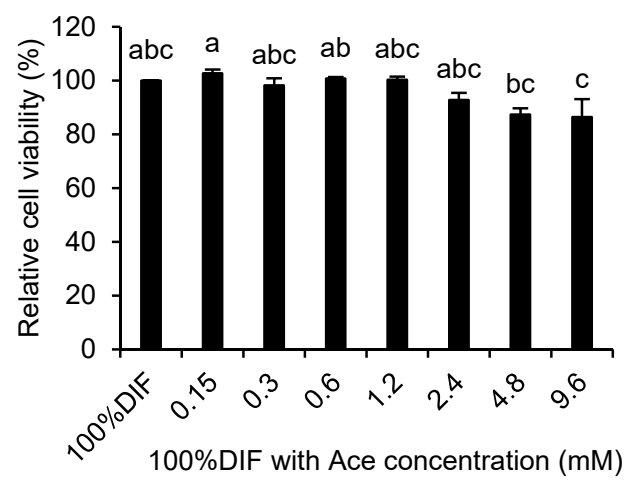

(c)

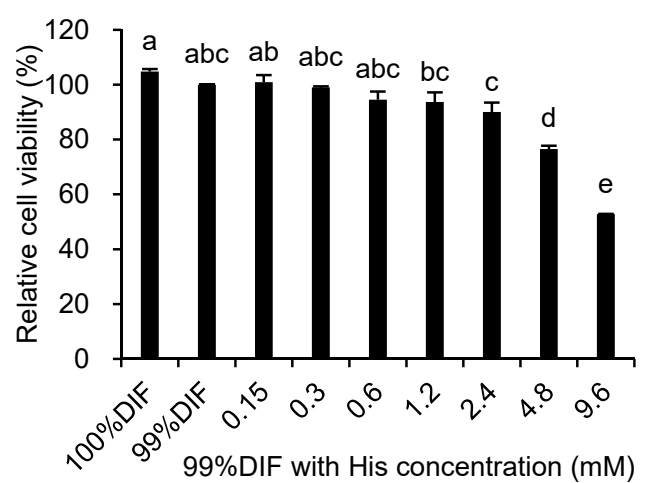

(b)

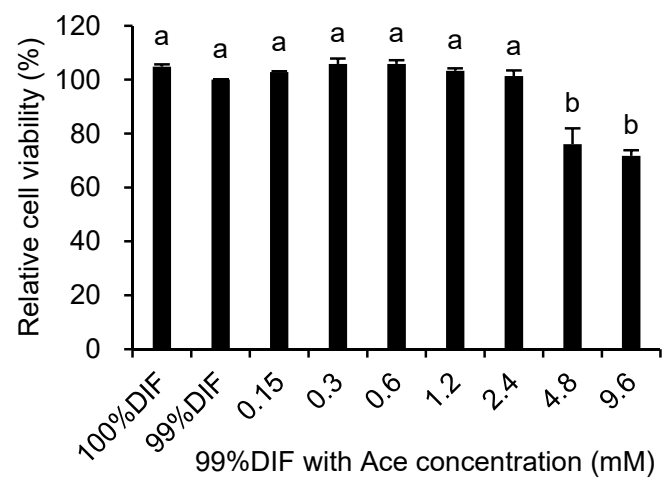

(d)

Figure 3. Effects of various concentrations of L-histidine (His) or sodium acetate (Ace) with the unrestricted (100\%) or 1\% nutrient-restricted (99\%) differentiation media (DIF) on the viability of the immortalized bovine mammary epithelial cells (MAC-T). The MAC-T cells were incubated with (a) 100\%DIF plus His, (b) 99\%DIF plus His, (c) 100\%DIF plus Ace, or (d) $99 \%$ DIF plus Ace for $24 \mathrm{~h}$. The values are presented as the mean $\pm \operatorname{SEM}(n=3)$. The means without a superscript letter differ (a-e), $p<0.05$.

The relative medium protein concentrations in the medium after the treatment of the MAC-T cells with His or Ace are shown in Figure 4. The treatment with His did not affect the protein concentration under the $100 \%$ DIF condition $(p>0.10$, Figure $4 a)$. The treatment with His under the NR condition showed similar patterns of cell viability $(p=0.003$, Figure $4 b)$. The addition of Ace into 100\%DIF dose-dependently increased the relative concentration of the secreted proteins ( $p=0.005$, Figure $4 c)$. Conversely, the Ace supplementation in $99 \%$ DIF dose-dependently decreased the relative concentration of the secreted proteins ( $p=0.005$, Figure $4 \mathrm{~d}$ ). Hence, the relative $\beta$-casein mRNA levels in the 
groups treated with $99 \%$ DIF and His or 100\%DIF with Ace were analyzed, as these groups showed statistically significant differences in cell viability.

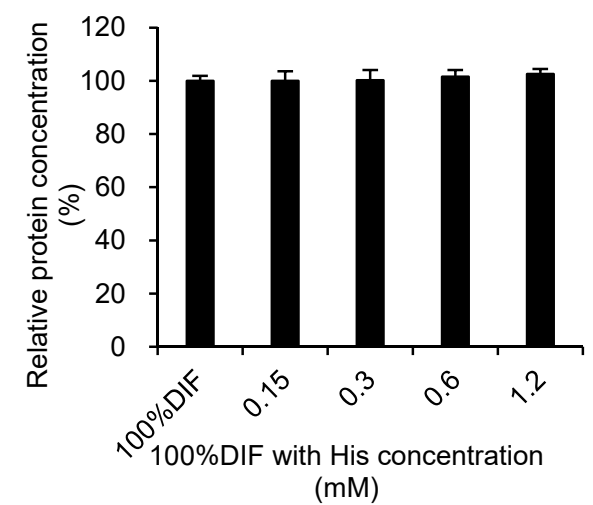

(a)

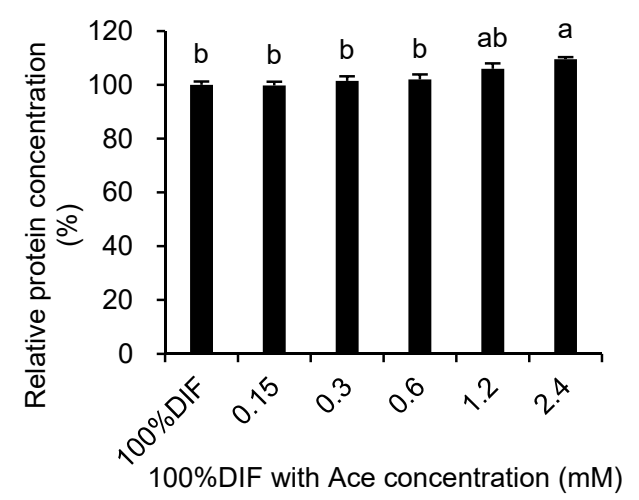

(c)

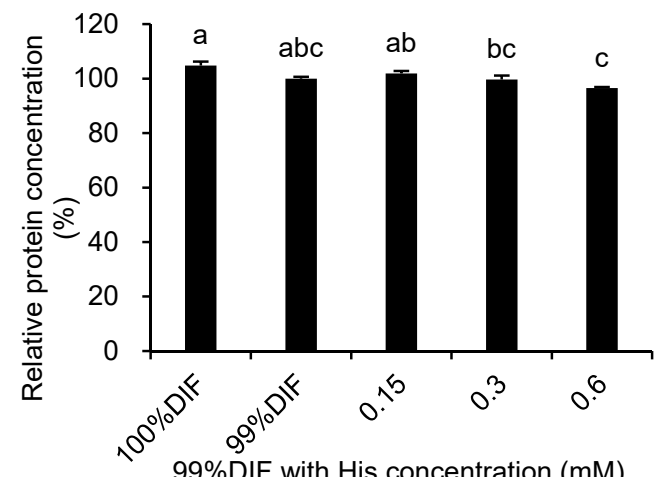

(b)

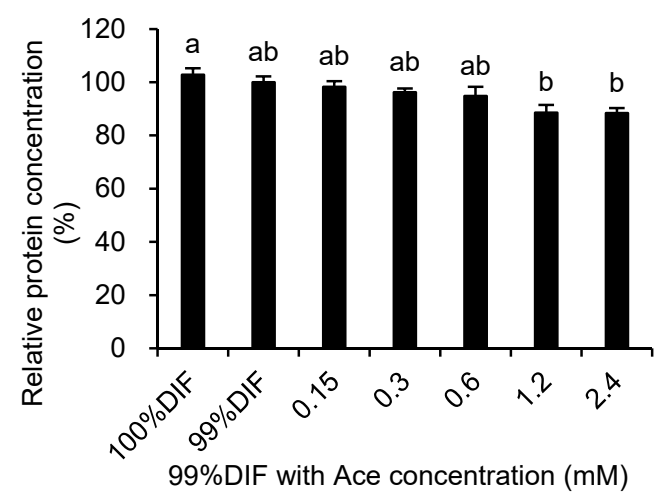

(d)

Figure 4. Effects of various concentration of L-histidine (His) or sodium acetate (Ace) with unrestricted (100\%) or $1 \%$ nutrient-restricted (99\%) differentiation media (DIF) on the relative protein concentrations in the culture medium of the immortalized bovine mammary epithelial cells (MAC-T). The MAC-T cells were incubated with (a) 100\%DIF plus His, (b) $99 \%$ DIF plus His, (c) 100\%DIF plus Ace, or (d) $99 \%$ DIF plus Ace for $24 \mathrm{~h}$. The values are presented as the mean \pm SEM $(n=3)$. The means without a superscript letter differ $(\mathrm{a}-\mathrm{c}), p<0.05$.

The effects of His, Ace, or NR on the relative $\beta$-casein mRNA expression are presented in Figure 5. The multiple comparisons were not observed between the treatment groups. For the His-treated groups, $0.15 \mathrm{mM}$ with $99 \% \mathrm{DIF}$ increased the relative expression of $\beta$-casein 2.2-fold compared to $99 \%$ DIF without His supplementation ( $p=0.014$, Figure $5 \mathrm{a}$ ). The delta $\mathrm{Ct}$ values of each treatment in Figure 5a were as follows: $100 \%$ DIF $=9.82$, $99 \%$ DIF $=10.77,99 \%$ DIF with $0.15 \mathrm{mM}$ of His $=9.07,99 \%$ DIF with $0.3 \mathrm{mM}$ of His $=9.42$, $99 \%$ DIF with $0.6 \mathrm{mM}$ of His $=10.96,99 \%$ DIF with $1.2 \mathrm{mM}$ of His $=9.73$, and $99 \%$ DIF with $2.4 \mathrm{mM}$ of His $=10.76$. The stimulatory effect of Ace on the $\beta$-casein mRNA level was observed under the $100 \%$ DIF condition $(p<0.05$, Figure $5 b)$. When $0.15,0.3$, or $0.6 \mathrm{mM}$ of Ace was supplemented in the $100 \%$ DIF condition, the $\beta$-casein mRNA level was increased 1.4-fold, 1.7-fold, and 2.1-fold, respectively, compared to the 100\%DIF condition. The delta Ct values of each treatment in Figure $5 \mathrm{~b}$ were as follows: $100 \% \mathrm{DIF}=13.45,100 \%$ DIF with $0.15 \mathrm{mM}$ of Ace $=12.19,100 \%$ DIF with $0.3 \mathrm{mM}$ of Ace $=12.08,100 \% \mathrm{DIF}$ with $0.6 \mathrm{mM}$ of Ace $=11.95,100 \%$ DIF with $1.2 \mathrm{mM}$ of Ace $=12.53$, and $100 \%$ DIF with $2.4 \mathrm{mM}$ of Ace $=12.79$. Therefore, based on $0.15 \mathrm{mM}$ of His, which revealed an increase in the $\beta$-casein mRNA level, an additional experiment was conducted in order to confirm the combination effect of His and Ace. 


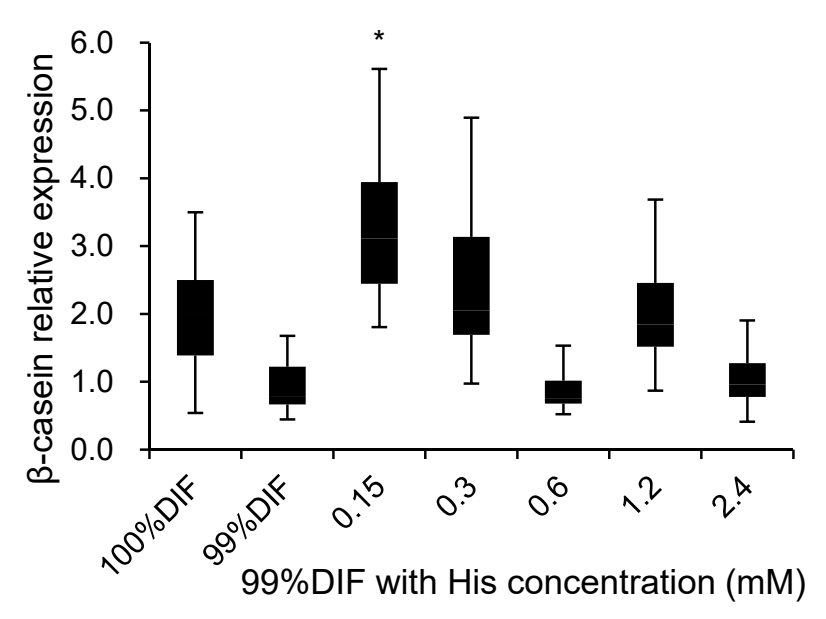

(a)

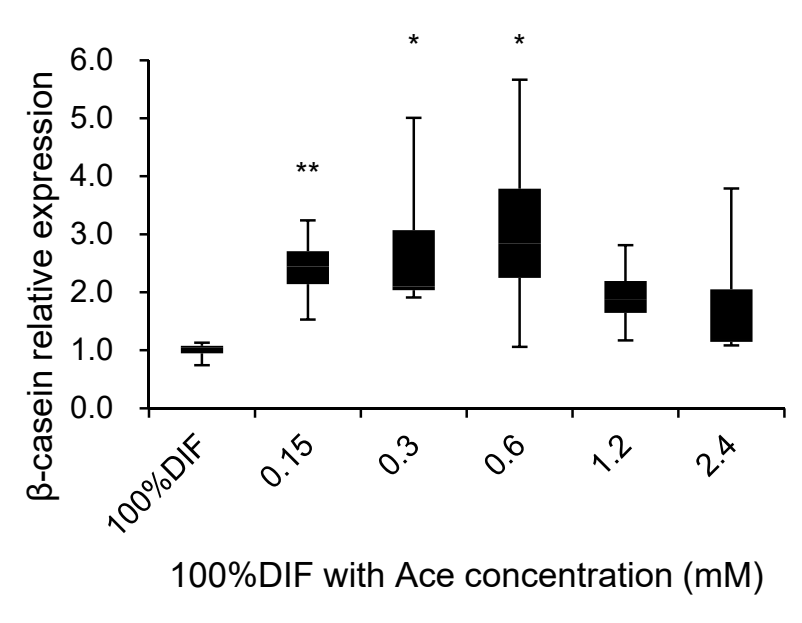

(b)

Figure 5. Effects of various concentrations of L-histidine (His) or sodium acetate (Ace) with unrestricted (100\%) or 1\% nutrient-restricted (99\%) differentiation media (DIF) on the $\beta$-casein mRNA expression in immortalized bovine mammary epithelial cells (MAC-T). The MAC-T cells were incubated with (a) 99\%DIF plus His, or (b) 100\%DIF plus Ace for 24 h. The values are presented as the median and interquartile ranges $(n=3)$. Significant difference compared to the control was presented as ${ }^{*} p<0.05,{ }^{* *} p<0.01$.

\subsection{Combination Effects of His and Ace in the NR Condition}

The effects of NR or $0.15 \mathrm{mM}$ of His plus various concentrations of Ace on the MAC-T cells are presented in Figure 6. The relative cell viability was decreased by Ace dosedependently in both the NR and unrestricted conditions $(p<0.001$, Figure 6a). Therefore, six treatments were selected for the further analyses. When $0.15 \mathrm{mM}$ of His and Ace was supplemented in the $100 \%$ DIF condition, the relative protein concentration in the medium was increased significantly compared to the other groups, except for the $100 \%$ DIF group ( $p=0.002$, Figure $6 \mathrm{~b}$ ). However, the mRNA expression levels of $\beta$-casein were increased 1.7-fold and 1.6-fold in the treatment groups of His and His plus Ace with $99 \%$ DIF ( $p=0.003$, Figure $6 \mathrm{c}$ ). The delta Ct values of each treatment in Figure $6 \mathrm{c}$ were as follows: $100 \% \mathrm{DIF}=13.45,99 \% \mathrm{DIF}=13.68,99 \% \mathrm{DIF}$ with $0.15 \mathrm{mM}$ of His $=12.16,99 \% \mathrm{DIF}$ with $0.15 \mathrm{mM}$ of His and Ace $=12.24,100 \%$ DIF with $0.15 \mathrm{mM}$ of His $=13.38$, and $100 \%$ DIF with $0.15 \mathrm{mM}$ of His and Ace $=13.40$.

The relative expression levels of the genes involved in protein synthesis and nutrient transportation after treatment with His, Ace, or NR are presented in Table 2. The treatments did not affect the mRNA expression levels of sodium-dependent neutral amino acid transporter type $2(A S C T 2), m T O R$, or RPS6 $(p>0.10)$. However, the mRNA level of large neutral amino acids transporter small subunit 1 (LAT1) in the group treated with $0.15 \mathrm{mM}$ His plus $0.15 \mathrm{mM}$ Ace in $100 \%$ DIF was increased compared to that in other groups $(p=0.004)$. The expression levels of LAT1 and glucose transporter 1 (GLUT1) were increased by $39 \%$ and $45 \%$ in the $100 \%$ DIF condition compared to those in the $99 \%$ DIF condition, respectively $(p<0.01)$. A significant combination effect of His and Ace on the expression levels of $L A T 1$ and S6K1 compared to the 100\%DIF condition was observed when the nutrient was not restricted $(p<0.01)$. 


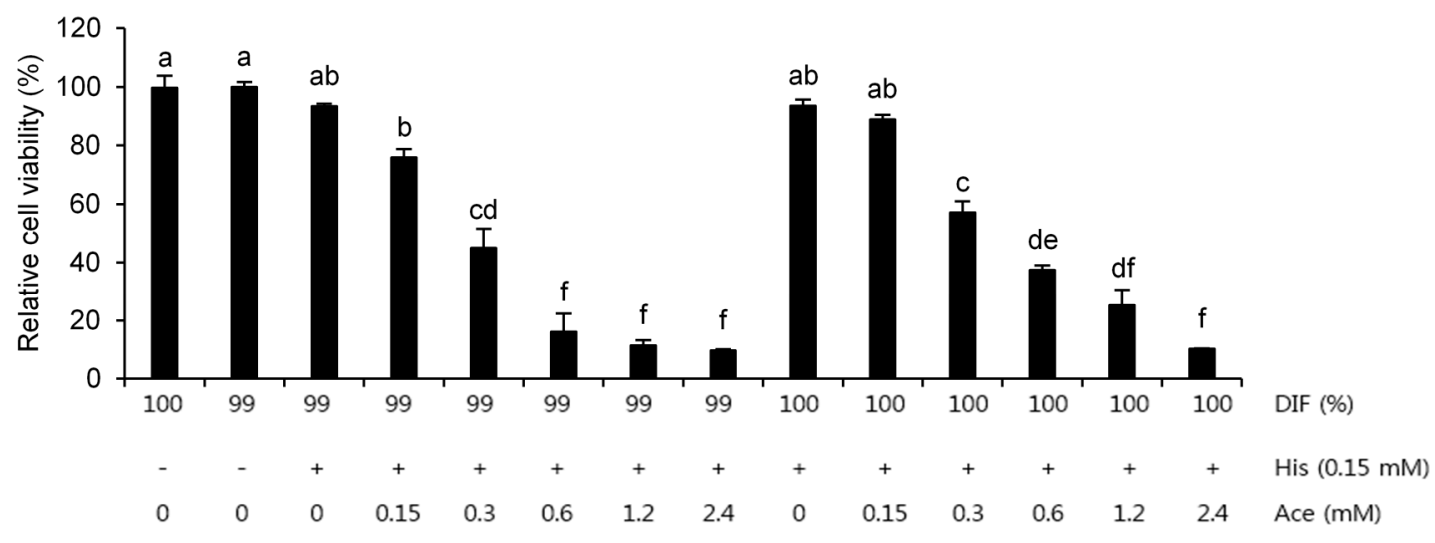

(a)

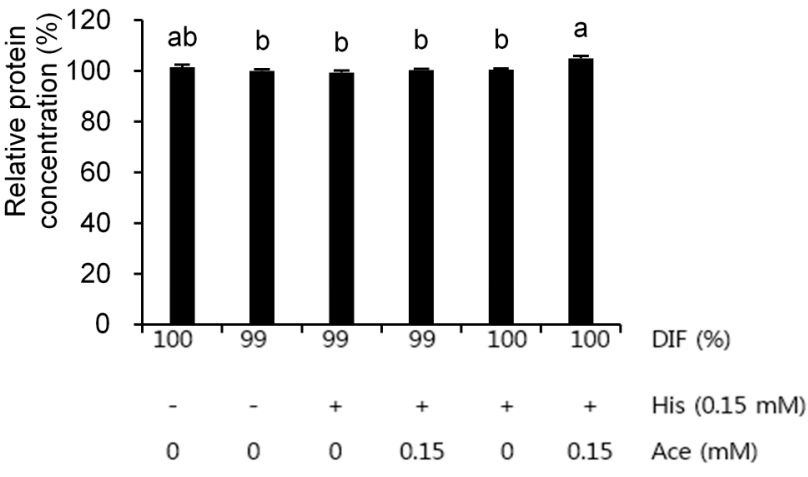

(b)

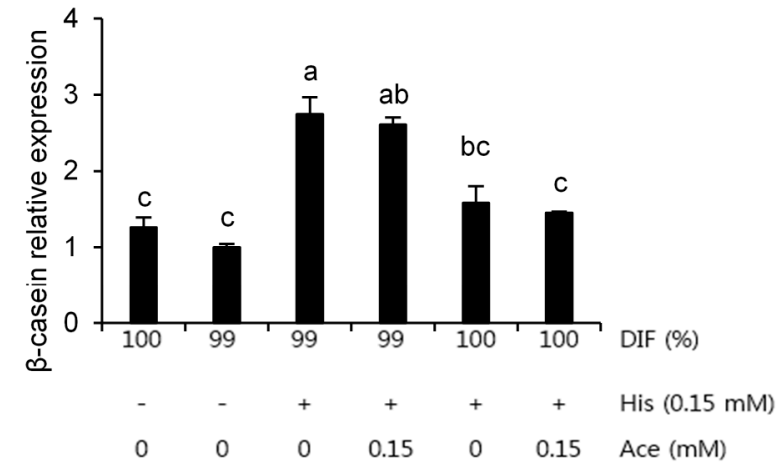

(c)

Figure 6. Effects of $0.15 \mathrm{mM}$ of L-histidine (His) plus various concentrations of sodium acetate (Ace) with unrestricted $(100 \%)$ or $1 \%$ nutrient-restricted $(99 \%)$ differentiation media (DIF) on (a) the relative cell viability, (b) the relative protein concentration in the cultured medium, and (c) the $\beta$-casein mRNA expression in the immortalized bovine mammary epithelial cells (MAC-T). The MAC-T cells were incubated for $24 \mathrm{~h}$ after each treatment. The values are presented as the mean $\pm \operatorname{SEM}(n=3)$. The means without a superscript letter differ $(\mathrm{a}-\mathrm{f}), p<0.05$.

Table 2. Effects of L-histidine and sodium acetate on the expression levels of nutrient transporters and the mammalian target of rapamycin pathway genes in nutrient-restricted or unrestricted immortalized bovine mammary epithelial cells.

\begin{tabular}{ccccccccc}
\hline \multicolumn{7}{c}{ Treatment $^{\mathbf{1 , 2}}$} \\
\hline \multicolumn{7}{c}{$\mathbf{9 9 \% D I F}+\mathbf{H i s}$} & $\mathbf{1 0 0 \% D I F}+\mathbf{H i s}$ \\
\hline Gene $^{3}$ & $\mathbf{9 9 \% D I F}$ & $\mathbf{1 0 0 \% D I F}$ & Ace - & Ace + & Ace - & Ace + & SEM $^{4}$ & $p$-Value \\
\hline ASCT2 & 1.00 & 1.09 & 0.79 & 0.86 & 1.11 & 1.32 & 0.11 & 0.314 \\
LAT1 & $1.00^{\mathrm{b}}$ & $1.39^{\mathrm{b} *}$ & $0.86^{\mathrm{b}}$ & $0.82^{\mathrm{b}}$ & $1.02^{\mathrm{b}}$ & $1.84^{\text {a\# }}$ & 0.13 & 0.004 \\
GLUT1 & 1.00 & $1.45^{*}$ & 0.85 & 1.08 & 0.99 & 1.38 & 0.13 & 0.068 \\
mTOR & 1.00 & 1.05 & 0.87 & 0.93 & 0.97 & 1.16 & 0.06 & 0.582 \\
S6K1 & 1.00 & 0.99 & 0.98 & 1.02 & 0.96 & $1.38^{\#}$ & 0.05 & 0.221 \\
RPS6 & 1.00 & 0.97 & 1.06 & 0.95 & 1.00 & 1.00 & 0.02 & 0.590 \\
\hline
\end{tabular}

$199 \% \mathrm{DIF}=1 \%$ diluted differentiation medium; $100 \% \mathrm{DIF}=$ differentiation medium; His $=0.15 \mathrm{mM}$ of L-histidine Ace $=0.15 \mathrm{mM}$ of sodium acetate. ${ }^{2}$ Least squared means; $n=3$ ( $\mathrm{n}$ is the number of observations used in the statistical analysis). ${ }^{3}$ ASCT2 = sodium-dependent neutral amino acid transporter type 2; GLUT1 = glucose transporter 1; LAT1 = large neutral amino acids transporter small subunit 1; mTOR; mammalian target of rapamycin; $R P S 6=$ ribosomal protein $\mathrm{S6}$; S6K1 = ribosomal protein S6 kinase 1; UXT = ubiquitously expressed transcript protein. ${ }^{4} \mathrm{SEM}=$ standard error of the mean. ${ }^{\mathrm{a}-\mathrm{b}}$ Within a row, the means without a superscript letter differ $(p<0.05) .{ }^{*}$ A significant difference compared to $99 \% \mathrm{DIF}(p<0.05) .{ }^{\#}$ A significant difference compared to $100 \%$ DIF $(p<0.05)$. 


\section{Discussion}

When Holstein $\times$ Normande crossbreed dairy cows were in NR, the DNA concentration of their mammary glands was significantly decreased compared to unrestricted cows [19]. Moreover, the mammary glands of the NR cows showed more apoptotic cells and increased mRNA levels of apoptosis-related genes in the same study. Viable mammary epithelial cells exfoliated from the mammary glands tended to increase in the milk of NR Holstein cows compared to those in the control cows [20]. The aforementioned studies reported the decreased viability of mammary cells when the dairy cows were in the NR condition. These were distinguished in our study (in vivo vs. in vitro); however, similar results were observed with our cell viability results in experiment 1.

Studies on the AA supply in mammary epithelial cells have reported increased cell viability through AA; however, a high dose of AA inversely decreased the viability $[4,21,22]$. Similarly to the results of other AAs, the supplementation of His in an AA-devoid cell medium increased the relative growth rate of Chinese mammary epithelial (CMEC-H) cells compared to the control, and an excess dose of His decreased the cell growth rate [4]. This partially agreed with the results of our study. The lack of an increase in the relative cell viability was probably due to the use of an AA-adequate medium in this study. His was supplemented to the AA-containing medium; a high concentration of AA in the medium may have had adverse effects on the cell viability. The supplementation of 4-8 mM Ace increased the relative growth rate in pbMECs [23]. The cell viability was not affected by supplementation with $0.25-5 \mathrm{mM}$ Ace in primary bovine mammary epithelial cells (pbMECs) isolated from mammary tissues [24]. This is consistent with our results using MAC-T cells. These results suggest that a high dose of Ace has cell toxicity, and that MAC-T cells can show similar responses to pbMECs.

The relative expression of $\beta$-casein in CMEC-H cells was significantly increased when $0.15 \mathrm{mM}$ of His was supplemented in an AA-devoid medium $[4,11]$. Comparing these results and our previous study, the inclusion of $0.15 \mathrm{mM}$ His has the potential to stimulate $\beta$ casein synthesis, although in an AA-existent NR condition. Thus, $0.15 \mathrm{mM}$ His was selected for the verification of its combination effect with Ace. The supplementation of Ace presented an increase of the $\beta$-casein mRNA level in pbMECs cultured with DMEM/F12 [13]. This is consistent with our results when 0.15-0.6 mM Ace was supplemented to the MAC-T cells. The decrease of the protein concentration in the NR groups might be because the cells used supplemented Ace as an energy source. Therefore, as shown in Figure 5b, the present study suggests that Ace can stimulate $\beta$-casein expression when nutrients are abundant.

The relative cell viability was lowered by Ace in a dose-dependent manner. Ace did not show a great effect on the MAC-T cell viability in experiment 2; however, when Ace was mixed with $0.15 \mathrm{mM}$ His, the cell viability was dose-dependently decreased. Thus, the decrease of the MAC-T cell viability was considered to be due to the effect of His. It has been reported that Ace has a synergistic effect on secretory proteins when it is supplemented with AA. When Ace and methionine were used together to treat MAC-T cells with an AA-adequate medium, the quantity of the secreted proteins increased compared to that in the group treated with methionine alone [25]. In our results, a synergistic effect on the relative protein concentration in the cultured medium was observed when both $0.15 \mathrm{mM}$ of His and Ace were used for the treatment under normal conditions. The results suggest that a supply of Ace with His has stimulatory effects on protein synthesis. Some synergistic effects on $\beta$-casein expression were reported when Ace was treated with leucine [13] or methionine [25] in nutrient-abundant conditions. Although the protein concentration in the cultured medium was increased after the treatment with a combination of Ace and His, such a combination did not show a synergistic effect on $\beta$-casein mRNA expression under the $100 \%$ DIF condition. According to Gao et al. (2015), the supplementation of $0.15 \mathrm{mM}$ His to the CMEC-H cells mostly increased the expression of $\beta$-casein and $\mathrm{k}$-casein (compared to a further dose of His); however, the inclusion of $0.15 \mathrm{mM}$ His did not increase the $\alpha$ s1-casein expression. Thus, the increased protein concentration was maybe due to 
other caseins and proteins, rather than $\beta$-casein. Further research on various milk proteins is needed in order to determine the interaction between His and Ace.

ASCT2 is an AA transporter that absorbs branched-chain AAs, threonine, and some nonessential AAs; LAT1 transports essential AAs except Lys, Arg, and Thr [5]. In our previous study, the expression of ASCT2 was increased when $0.6 \mathrm{mM}$ of L-valine (Val) was supplemneted to MAC-T cells, whereas Val did not affect the LAT1 expression [14]. The supplementation of L-phenylalanine (Phe) did not affect the expression of ASCT2 or LAT1 either. Dai et al. (2019) reported that Met supplementation increased ASCT2 expression by through the seryl-tRNA synthetase-mediated $\beta$-casein synthetic pathway. Thus, the literature reported that the effects of various AAs on cells are different, and in the present study, it was found that His had no effect on the expression of AA transporters. GLUT1 is used as a major glucose tansporter in various cells and tissues, including the bovine mammary gland that absorbs basal glucose [26,27]. The expression of GLUT1 increased when glucose was supplemented to pbMECs [28]. When dairy cows were subjected to NR, the GLUT1 expression decreased in pbMECs from bovine milk from NR cows [29]. The reports suggest that the GLUT1 expression in MECs is influenced by their energy state. This is consistent with our finding that GLUT1 exression was increased in 100\%DIF compared to $99 \%$ DIF. Zhao et al. (2019) reported an increase of cellular ATP concents by the supplementation of Ace. Ace was not affected by the GLUT1 levels in this study; however, it may be a potential energy source in mammary epithelial levels.

Protein synthesis is regulated by the mTOR complex and its downstream pathway, including S6K1 and RPS6 [1]. mTOR signaling is a highly energy-requiring process, and is regulated by AA and energy sources $[1,6]$. Thus, various results have been reported for the regulation of mTOR pathway-related genes by AAs [30,31] or ratios of AAs [32-34]. An increase of $m T O R$ was observed when $0.15 \mathrm{mM}$ His was supplemented to CMEC-H cells cultured in an AA-devoid medium [4,11]. However, the changes of the mTOR expression between the groups were not confirmed in the present study. This might be explained by the different medium conditions: AA-devoid medium in previous studies $[4,11]$ and DMEM/F12 in the present study. The supplementation of 4-12 mM Ace increased the mTOR mRNA levels in pbMECs [13]. In the present study, $0.15 \mathrm{mM}$ Ace might have been a dose that was too low to increase the $m T O R$ expression. Previous reports have shown various responses of S6K1 expression with His supplementation: decrease [35], increase [4,11], and no change [31]. Although the results are inconsistent, the increase of S6K1 in the present study might be related to the use of an AA-containing medium. RPS6 is a downstream gene of $S 6 K 1$, and is stimulated by $S 6 K 1$. However, the gene network is highly comxplex; thus, increased S6K1 expression does not always stimulate RPS6 expression. The expression of total S6K1 was increased by a differing Lys:Met ratio (2.5:1) compared to the control (Lys:Met $=2.9: 1$ ) when the MAC-T cells were in the thermal neutral condition $\left(37^{\circ} \mathrm{C}\right)$; however, the total RPS6 was not changed [33]. The phosphorylation states of $m T O R$ and S6K1 were not changed by differing Lys:Thr, Lys:His, and Lys:Val ratios (2.1:1, 3.05:1, and 1.62:1, respectively) compared to the control; however, the RPS6 phosphorylation state was increased by these treatments [36].

His supplementation did not affect the mRNA levels of mTOR pathway-related genes. However, it increased the $\beta$-casein expression level in the NR groups. Thus, His might stimulate the expression of $\beta$-casein in the NR condition through other pathways. Further studies are needed in order to verify the effects of His when nutrients are limited.

\section{Conclusions}

Overall, 99\%DIF was selected as the NR condition for MAC-T cells. The supplementation of His dose-dependently decreased the cell viability regardless of the NR condition. The $\beta$-casein mRNA level clearly increased in the $0.15 \mathrm{mM}$ His-supplemented NR group. The group with Ace supplementation showed higher MAC-T cell viability than the Histreated groups. When Ace was used for the treatment under the normal medium condition, the expression of $\beta$-casein was increased. In combination with Ace, His dominantly af- 
fected the MAC-T cell viability. The relative protein concentration increased when $0.15 \mathrm{mM}$ of His and Ace were used for the treatment under normal conditions; however, the $\beta$-casein expression was increased by His alone, or when both His and Ace were supplemented in the NR condition. Overall, these results suggest that His has a potential to increase the expression of $\beta$-casein in MAC-T cells under NR.

Author Contributions: Conceptualization, J.K. and H.-G.L.; methodology, J.K.; investigation, J.K.; writing-original draft preparation, J.K.; writing—review and editing, H.-G.L.; visualization, J.K.; supervision, H.-G.L.; project administration, H.-G.L.; funding acquisition, H.-G.L. All authors have read and agreed to the published version of the manuscript.

Funding: This research was funded by Korea Institute of Planning and Evaluation for Technology in Flood, Agriculture, and Forestry (IPET) through the Agri-Bio Industry Technology Development Program, grant number 117030-3.

Institutional Review Board Statement: Not applicable.

Informed Consent Statement: Not applicable.

Data Availability Statement: The data presented in this study are available on request from the corresponding author.

Conflicts of Interest: The authors declare no conflict of interest. The funders had no role in the design of the study.

\section{References}

1. Kim, S.G.; Buel, G.R.; Blenis, J. Nutrient regulation of the mTOR complex 1 signaling pathway. Mol. Cells 2013, 35, 463-473. [CrossRef]

2. Appuhamy, J.A.; Nayananjalie, W.A.; England, E.M.; Gerrard, D.E.; Akers, R.M.; Hanigan, M.D. Effects of AMP-activated protein kinase (AMPK) signaling and essential amino acids on mammalian target of rapamycin (mTOR) signaling and protein synthesis rates in mammary cells. J. Dairy Sci. 2014, 97, 419-429. [CrossRef] [PubMed]

3. Dong, X.; Zhou, Z.; Wang, L.; Saremi, B.; Helmbrecht, A.; Wang, Z.; Loor, J. Increasing the availability of threonine, isoleucine, valine, and leucine relative to lysine while maintaining an ideal ratio of lysine: Methionine alters mammary cellular metabolites, mammalian target of rapamycin signaling, and gene transcription. J. Dairy Sci. 2018, 101, 5502-5514. [CrossRef]

4. Gao, H.; Zhao, S.; Zheng, N.; Zhang, Y.; Wang, S.; Zhou, X.; Wang, J. Combination of histidine, lysine, methionine, and leucine promotes $\beta$-casein synthesis via the mechanistic target of rapamycin signaling pathway in bovine mammary epithelial cells. $J$. Dairy Sci. 2017, 100, 7696-7709. [CrossRef] [PubMed]

5. Bionaz, M.; Loor, J.J. Gene networks driving bovine mammary protein synthesis during the lactation cycle. Bioinform. Biol. Insights 2011, 5, 83-98. [CrossRef] [PubMed]

6. Tokunaga, C.; Yoshino, K.; Yonezawa, K. mTOR integrates amino acid- and energy-sensing pathways. Biochem. Biophys. Res. Commun. 2004, 313, 443-446. [CrossRef]

7. Wang, X.; Proud, C.G. The mTOR pathway in the control of protein synthesis. Physiology 2006, 21, 362-369. [CrossRef]

8. Broderick, G.A.; Stevenson, M.J.; Patton, R.A.; Lobos, N.E.; Olmos Colmenero, J.J. Effect of supplementing rumen-protected methionine on production and nitrogen excretion in lactating dairy cows. J. Dairy Sci. 2008, 91, 1092-1102. [CrossRef]

9. Giallongo, F.; Hristov, A.N.; Oh, J.; Frederick, T.; Weeks, H.; Werner, J.; Lapierre, H.; Patton, R.A.; Gehman, A.; Parys, C. Effects of slow-release urea and rumen-protected methionine and histidine on performance of dairy cows. J. Dairy Sci. 2015, 98, 3292-3308. [CrossRef]

10. Lee, C.; Hristov, A.N.; Cassidy, T.W.; Heyler, K.S.; Lapierre, H.; Varga, G.A.; de Veth, M.J.; Patton, R.A.; Parys, C. Rumen-protected lysine, methionine, and histidine increase milk protein yield in dairy cows fed a metabolizable protein-deficient diet. J. Dairy Sci. 2012, 95, 6042-6056. [CrossRef]

11. Gao, H.N.; Hu, H.; Zheng, N.; Wang, J.Q. Leucine and histidine independently regulate milk protein synthesis in bovine mammary epithelial cells via mTOR signaling pathway. J. Zhejiang Univ. Sci. B 2015, 16, 560-572. [CrossRef]

12. Sheng, R.; Yan, S.; Qi, L.; Zhao, Y.; Jin, L.; Guo, X. Effect of the ratios of acetate and $\beta$-hydroxybutyrate on the expression of milk fat-and protein-related genes in bovine mammary epithelial cells. Czech J. Anim. Sci. 2015, 60, 531-541. [CrossRef]

13. Zhao, Y.; Yan, S.; Chen, L.; Shi, B.; Guo, X. Effect of interaction between leucine and acetate on the milk protein synthesis in bovine mammary epithelial cells. Anim. Sci. J. 2019, 90, 81-89. [CrossRef]

14. Kim, J.; Lee, J.-E.; Lee, J.-S.; Park, J.-S.; Moon, J.-O.; Lee, H.-G. Phenylalanine and valine differentially stimulate milk protein synthetic and energy-mediated pathway in immortalized bovine mammary epithelial cells. J. Anim. Sci. Technol. 2020, 62, 263-275. [CrossRef] [PubMed]

15. Wang, T.; Jeon, S.W.; Jung, U.S.; Kim, M.J.; Lee, H.G. 1-Lactate Dehydrogenase B Chain Associated with Milk Protein Content in Dairy Cows. Animals 2019, 9, 442. [CrossRef] [PubMed] 
16. Wang, T.; Lim, J.N.; Bok, J.D.; Kim, J.H.; Kang, S.K.; Lee, S.B.; Hwang, J.H.; Lee, K.H.; Kang, H.S.; Choi, Y.J.; et al. Association of protein expression in isolated milk epithelial cells and cis-9, trans-11 conjugated linoleic acid proportions in milk from dairy cows. J. Sci. Food Agric. 2014, 94, 1835-1843. [CrossRef] [PubMed]

17. Bionaz, M.; Loor, J.J. Identification of reference genes for quantitative real-time PCR in the bovine mammary gland during the lactation cycle. Physiol. Genom. 2007, 29, 312-319. [CrossRef]

18. Jedrzejczak, M.; Szatkowska, I. Bovine mammary epithelial cell cultures for the study of mammary gland functions. In Vitro Cell. Dev. Biol. Anim. 2014, 50, 389-398. [CrossRef]

19. Dessauge, F.; Lollivier, V.; Ponchon, B.; Bruckmaier, R.; Finot, L.; Wiart, S.; Cutullic, E.; Disenhaus, C.; Barbey, S.; Boutinaud, M. Effects of nutrient restriction on mammary cell turnover and mammary gland remodeling in lactating dairy cows. J. Dairy Sci. 2011, 94, 4623-4635. [CrossRef]

20. Herve, L.; Quesnel, H.; Veron, M.; Portanguen, J.; Gross, J.J.; Bruckmaier, R.M.; Boutinaud, M. Milk yield loss in response to feed restriction is associated with mammary epithelial cell exfoliation in dairy cows. J. Dairy Sci. 2019, 102, 2670-2685. [CrossRef]

21. Dai, W.; Zhao, F.; Liu, J.; Liu, H. ASCT2 is involved in SARS-mediated $\beta$-casein synthesis of bovine mammary epithelial cells with methionine supply. J. Agric. Food Chem. 2019, 68, 13038-13045. [CrossRef] [PubMed]

22. Lin, X.; Li, S.; Zou, Y.; Zhao, F.Q.; Liu, J.; Liu, H. Lysine Stimulates Protein Synthesis by Promoting the Expression of ATB0,+ and Activating the mTOR Pathway in Bovine Mammary Epithelial Cells. J. Nutr. 2018, 148, 1426-1433. [CrossRef] [PubMed]

23. Zhao, Y.; Guo, X.; Yan, S.; Shi, B.; Sheng, R. Acetate regulates milk fat synthesis through the mammalian target of rapamycin/eukaryotic initiation factor 4E signaling pathway in bovine mammary epithelial cells. J. Dairy Sci. 2021, 104, 337-345. [CrossRef] [PubMed]

24. Wei, Z.; Xiao, C.; Guo, C.; Zhang, X.; Wang, Y.; Wang, J.; Yang, Z.; Fu, Y. Sodium acetate inhibits Staphylococcus aureus internalization into bovine mammary epithelial cells by inhibiting NF-kB activation. Microb. Pathog. 2017, 107, 116-121. [CrossRef]

25. Jeon, S.W.; Conejos, J.R.; Kim, J.; Kim, M.J.; Lee, J.E.; Lee, B.S.; Park, J.S.; Moon, J.O.; Lee, J.S.; Lee, H.G. Supplementing conjugated and non-conjugated L-methionine and acetate alters expression patterns of CSN2, proteins and metabolites related to protein synthesis in bovine mammary cells. J. Dairy Res. 2020, 87, 70-77. [CrossRef] [PubMed]

26. Zhao, F.Q. Biology of glucose transport in the mammary gland. J. Mammary Gland Biol. Neoplasia 2014, 19, 3-17. [CrossRef]

27. Zhao, F.Q.; Keating, A.F. Expression and regulation of glucose transporters in the bovine mammary gland. J. Dairy Sci. 2007, 90 (Suppl. 1), E76-E86. [CrossRef]

28. Lin, Y.; Sun, X.; Hou, X.; Qu, B.; Gao, X.; Li, Q. Effects of glucose on lactose synthesis in mammary epithelial cells from dairy cow. BMC Vet. Res. 2016, 12, 81. [CrossRef]

29. Boutinaud, M.; Ben Chedly, M.H.; Delamaire, E.; Guinard-Flament, J. Milking and feed restriction regulate transcripts of mammary epithelial cells purified from milk. J. Dairy Sci. 2008, 91, 988-998. [CrossRef] [PubMed]

30. Zhang, M.C.; Zhao, S.G.; Wang, S.S.; Luo, C.C.; Gao, H.N.; Zheng, N.; Wang, J.Q. d-Glucose and amino acid deficiency inhibits casein synthesis through JAK2/STAT5 and AMPK/mTOR signaling pathways in mammary epithelial cells of dairy cows. J. Dairy Sci. 2018, 101, 1737-1746. [CrossRef]

31. Zhou, Y.; Zhou, Z.; Peng, J.; Loor, J.J. Methionine and valine activate the mammalian target of rapamycin complex 1 pathway through heterodimeric amino acid taste receptor (TAS1R1/TAS1R3) and intracellular $\mathrm{Ca}^{2+}$ in bovine mammary epithelial cells. J. Dairy Sci. 2018, 101, 11354-11363. [CrossRef] [PubMed]

32. Hu, L.; Chen, Y.; Cortes, I.M.; Coleman, D.N.; Dai, H.; Liang, Y.; Parys, C.; Fernandez, C.; Wang, M.; Loor, J.J. Supply of methionine and arginine alters phosphorylation of mechanistic target of rapamycin (mTOR), circadian clock proteins, and alpha-s1-casein abundance in bovine mammary epithelial cells. Food Funct. 2020, 11, 883-894. [CrossRef]

33. Salama, A.A.K.; Duque, M.; Wang, L.; Shahzad, K.; Olivera, M.; Loor, J.J. Enhanced supply of methionine or arginine alters mechanistic target of rapamycin signaling proteins, messenger RNA, and microRNA abundance in heat-stressed bovine mammary epithelial cells in vitro. J. Dairy Sci. 2019, 102, 2469-2480. [CrossRef] [PubMed]

34. Wang, F.; van Baal, J.; Ma, L.; Loor, J.J.; Wu, Z.L.; Dijkstra, J.; Bu, D.P. Short communication: Relationship between lysine/methionine ratios and glucose levels and their effects on casein synthesis via activation of the mechanistic target of rapamycin signaling pathway in bovine mammary epithelial cells. J. Dairy Sci. 2019, 102, 8127-8133. [CrossRef] [PubMed]

35. Prizant, R.L.; Barash, I. Negative effects of the amino acids Lys, His, and Thr on S6K1 phosphorylation in mammary epithelial cells. J. Cell. Biochem. 2008, 105, 1038-1047. [CrossRef] [PubMed]

36. Li, S.S.; Loor, J.J.; Liu, H.Y.; Liu, L.; Hosseini, A.; Zhao, W.S.; Liu, J.X. Optimal ratios of essential amino acids stimulate beta-casein synthesis via activation of the mammalian target of rapamycin signaling pathway in MAC-T cells and bovine mammary tissue explants. J. Dairy Sci. 2017, 100, 6676-6688. [CrossRef] [PubMed] 